\title{
PENGARUH PEMBERIAN PUPUK ORGANIK CAIR (POC) ASAL LIMBAH TUMBUHAN TERHADAP SERAPAN HARA DAN N DAN P SERTA PRODUKSI TANAMAN KEDELAI ( glycine max (L) merril) DI LAHAN GAMBUT
}

\author{
Hendra Saputra1, Nursida2 Dan Intan Sari2 \\ Program Studi Agroteknologi Fakultas Pertanian \\ Universitas Islam Indragiri
}

\begin{abstract}
Abstrak
Penelitian tentang pengaruh pemberian pupuk organic cair (POC) asal limbah tumbuhan serapan hara $N$ dan $p$ serta produksi tanaman kedelai (Glicynine Max (L) Merril) di lahan gambut telah dilaksanakan di kampus II Unisi Fakultas Pertanian jl. Lintas Propinsi parit 01, Desa Pulau Palas, Kecamatan Tembilahan Hulu, Kabupaten Indragiri Hilir Propinsi Riau. Dimulai dari bulan agustussampai bulan oktober 2013. Tujuan dari penelitian ini untuk mendapatkan Poc asal limbah tumbuhan yang terbaik untuk serapan hara $N$ dan $p$ serta produksi tanaman kedelai di lahan gambut. Penelitian ini menggunakan rancangan acak kelompok (RAK) factor tunggall dengan 7 perlakuan dan 4 ulangan, 2 tanaman dijadikan samp;el.. Perlakuan dosis POC limbah tanaman pisang dan POC limbah sayur kol yang diberikan yaitu $0 \mathrm{~L} / \mathrm{Ha}$, 400L/Ha dan $600 \mathrm{~L} / \mathrm{Ha}$. Parameter pengamatan yaitu : serapan hara $N$ dan $p$ pada fase awal generative, tinggi tanaman, jumlah bintil akar,polong hampa, produksi perplot, berat 100 biji dan brangkasan kering. Data pengamatan dianalisis dengan sidik ragam (ANOVA) dan dilanjutkan dengan uji lanjut tukey HSD pada taraf $5 \%$. Berdasarkan penelitian yang telah dilaksanakan dapat disimpulkan bahwa pemberian POC asal limbah tumbuhan tidak berpengaruh nyata terhadap serapan hara $n$ dan $p$, tinggi tanaman, jumlah bintil akar, polong hampa, brangkasan kering tetapi berpengaruh nyata terhadap produksi perplot dan berat 100 biji.
\end{abstract}

Kata kunci : pupuk organik cair,serapan hara $N, \& P$, kedelai, gambut.

\begin{abstract}
Research on the effect of administering liquid organic fertilizer (POC) from $N$ and $p$ nutrient uptake of plant nutrients and the production of soybean (Glicynine Max (L) Merril) on peatlands has been carried out on campus II of Unisi Faculty of Agriculture jl. Cross Provincial Trench 01, Pulau Palas Village, Tembilahan Hulu District, Indragiri Hilir Regency, Riau Province. Starting from August to October 2013. The purpose of this study was to obtain the best Poc from plant waste for $N$ and $P$ nutrient uptake as well as soybean crop production in peatlands. This study used a single randomized block design (RBD) factor with 7 treatments and 4 replications, 2 plants were used as samples. The treatment of POC dosage of banana plant waste and POC of vegetable cabbage waste were given ie $\mathrm{O} \mathrm{L} / \mathrm{Ha}$, $400 \mathrm{~L} / \mathrm{Ha}$ and $600 \mathrm{~L} / \mathrm{Ha}$. Observation parameters were: $N$ and $P$ nutrient uptake in the early generative phase, plant height, number of root nodules, hollow pods, plot production, weight of 100 seeds and dry stover. Observation data were analyzed by variance analysis (ANOVA) and continued with HSE tukey test at 5\% level. Based on the research that has been carried out, it can be concluded that the administration of POC from plant waste has no significant effect on nutrient uptake of $n$ and $p$, plant height, number of root nodules, empty pods, dry stover but significant effect on plot production and weight of 100 seeds.
\end{abstract}

Keywords: liquid organic fertilizer, $N, \&$ P nutrient uptake, soybean, peat. 


\section{Pendahuluan}

Kedelai (glycine max (L) merril ) merupakan komoditas tanaman pangan yang mempunyai nilai tinggi dan sangat diminati oleh hamper semua masyarakat. Kacang-kacangan seprerti kedelai merupakan bahan pangan, sumber protein dan lemak nabati yang sangat penting peranannaya dalam kehidupan ( Cahyadi, 2007 ). Proyeksi konsumsi kedelai menurut simatupang et al, (2005) dalam atman (2009) menunjukkan total kebuuhan kedelai di Indonesia terus mengalami peningkatan dari 2,35 juta ton pada tahun 2009 menjadi 2,71 juta ton pada tahun 2015 dan 3,35 juta ton pada tahun 2005. Juka sasaran produktifitas rata-rata nasional 1,5 ton/Ha bisa dicapai maka kebutuhan areal tanam akan diperkirakan sebesar 1,81 juta ha pada tahun 2015 dan 2,24 juta ha pada tahun 2025 sementara areal produtif semakin berkurang. Oleh karena itu untk meningkatkan produksi kedelai melalui identifikasi lahan-lahan produktif dimasa mendatang semakin sulit dilakukan. Hak ini menyebabkan meningkatnya pengugunaan lahan marginal termasuk tanah gambut.

Permasalahan yang sering terjadi pada budidaya tanaman kedelai di tanah gambut yaitu rendahnya produksi kedelai akibat tinggnya tingkat kemasaman di tanah gambut sehingga menyebabkan rendahnya ketersediaan hara bagi tanaman kedelai. Rendahnya ketersediaan hara tanah akan menyebabkan rendahnya serapan har oleh jaringan tanaman. Sehingga dengan demikian perlu adanya upaya pemberian unsure hara yang dapat meningkatkan serapan hara dudalam jaringan tanaman sehingga diharapkan dengan meningkatkan serapan unsure hara oleh jaringan tanaman akan mampu meningkatkan produksi tanaman.

Penelitian ini bertujuan untuk mengetahui pengaruh pemberian pupuk organic cair terhadap serapan hara dan mengetahui berapakah peningkatan produksi pada tanaman kedelai (glycine max (L) merril ) dengan pemberian pupuk organik cair asal limbah tumbuhan.

Penelitian ini diharapkan dapat memberikan kontribusi kontribusi nyata terhadap produksi tanaman kedelai ( glycine max $(\mathrm{L})$ merril) di lahan gambut dengan pemanfaatan limbah tumbuhan limbah tumbuhan sebagai pupuk organic cair.

\section{Tinjauan Pustaka}

\subsection{Tanah Gambut Dan Permasalahannya}

Gambut dalam taksonomi tanah ( soil srvey staff, 1975) didefinisikan sebagai tanah yang mengandung bahan organic lebih dari $20 \%$ ( bila tanah tidak mengandung liat ) atau lebih dari $30 \%$ ( bila tanah mengandung liat $60 \%$ atau lebih ) dan tebalnya secara komulatiflebih dari $40 \mathrm{~cm}$ ( harjowigeno, 1989).

Tanah gambut didaerah tropis dari bahan penyusun yang berasal dari kayu-kayuan, dalam keadaan tergenang, drainase yang buruk, adanya lapisan sulfat masam, Ph rendah diikuti status kesuburan tanah yang sangat rendah. Pengembangan usaha pertanian sangat dibatasi oleh kendala-kendala tersebut diatas ( harjowigeno, 1989).

2.2. morfologi tanaman kedelai
Secara taksonomi tanaman kedelai diklasifikan sebagai berikut

$\begin{array}{lll}\text { Kingdom } & : & \text { Plantae } \\ \text { Divisi } & : & \text { Spermatophyte } \\ \text { Subsidi } & : & \text { Angiospermae } \\ \text { Kelas } & : & \text { Dicotydonae } \\ \text { Ordo } & : & \text { Polypetales } \\ \text { Family } & : & \text { Legominos } \\ \text { Subfamily } & : & \text { Papilionoidae } \\ \text { Genus } & : & \text { Glyycine } \\ \text { Spesies } & : & \text { Glycine Max }\end{array}$

\subsection{Syarat Tumbuh}

Tanah dan ikim merupakan dua komponen lingkungan tumbuh yang berpengaruh pada pertumbuhan tanaman kedelai. Pertumbuhan kedelai tidak bisa optimal bila tumbuh pada lingkungan dengan salah satu komponen tumbuh optimal. Hal ini dikarenakan kedua komponen ini harus saling mendukung satu sama lain sehingga pertumbuhan kedelai bias optimall. ( suprapto, 2002).

\subsection{Mikroorganisme Penambat Nitrogen}

Akar-akar tanaman yang masih hidup mempengaruh keseimbangan hara tanah akibat penyerapan unsur-unsur hara oleh akar tanaman. Disamping itu akar juga mempunyai pengaruh langsung terhadap ketersediaan insur hara karena dapat membentuk asam-asam organic dipermukaannya yang dapat meningkatkan kelarutan unsur hara. Dikeluarkannya asam amino yang mudah dihancurkan dan terlepasnya beberapa bagian kulit akar akan meningkatkan aktivitas mikroorganisme disekitar akar. Jumlah organisme disekitar akar ( rhizospermae) umummnya berkisar antara 10-100 kali lebih banyak dari pada dluar daerah perakaran. Dengan demikian jelaslah bahwa ketersediaan unsur hara sangat dipengaruhi oleh akar (Root exudates) dan aktivitas mikroorganisme di Rhizosphere / daerah perakaran ( Hardjowigeno, 2003).

\subsection{Pupuk Organic Cair ( POC}

Pupuk organic cair yang berasal dari llimbah tumbuhan merupakan sumber energy da substrat yang baik pertumbuhan mikroorganisme disekitar perakaran tanaman. Mikroorganisme tanah merupakan salah satu factor utama yang mempengaruhi kesuburan tanah sebagian besar pertumbuhan tanman tidak terlepas dari peran mikroorganisme tanah.

\section{Bahan Dan Metode}

\subsection{Waktu Dan Tempat}

Penelitian ini dilaksanakan di kampus parit II kampus Unisi Fakultas Pertanian Jl. Lintas Propinsi Parit 01, Desa Pulau Palas, Kecamatan Tembilahan Hulu, Kabupaten Indragiri Hilir Propinsi 
Riau. Waktu penilitian dilaksanakan mulai bulan Agustus sampai dengan bulan Oktober tahun 2013.

\subsection{Bahan Dan Alat}

Bahan-bahan dalam percobaan ini adalah benih kedelai varietas anjasmoro, pupuk organic cair cair dari limbah tanaman pisang dan limbah sayur, insektisida Regent dan fungisida Dhithane M-25. Peralatan yang digunakan adalah tong, cangkul, parang, ember, hand sprayer, gergaji, meteran, kamera, alat tulis dan peralatan laboratorium, timbangan analitik, Ph meter dan oven.

\subsection{Metode Penelitian}

Peneletian ini dilakukan dengan menggunakan rancangan acak kelompok (RAK) fakor tunggal dengan 7 perlakuann diantaranya :

A : Tanpa pembaerian $\mathrm{POC}$

B : POC limbah tanaman pisang (batang dan bonggol pisang ) 7,5 $\mathrm{CC} /$ liter air

C : POC limbah tanaman pisang ( batang dan bonggol pisang ) 15 $\mathrm{cc} /$ liter air

D : POC limbah tanaman pisang (batang dan bonggol pisang) 22,5 $\mathrm{cc} /$ liter air

E : POC limbah sayuran kol 7,5 cc/liter

$\mathrm{F}$ : POC limbah sayuran kol $15 \mathrm{cc} / \mathrm{liter}$ air

G : POC limbah sayuran kol 22,5 cc/liter air

\subsection{Pelaksanaan Penelitian}

Adapun rincian kegiatan dalam penelitian ini dapat diuraikkan dengan beberapa kegiatan diantara nya adalah pembuatan POC, persiapan lahan, pemasangan lebel pada plot, analisis tanah awal dan analisis kandungan hara POC, penanaman, pemberian pupuk organic cair, pemeliharaan, peenyiraman, penyulaman, penjarangan, penyiangan, pengendalian hama penyait, pemanenan.

\subsection{Pengamatan}

Yang diamati adalah jumlah bintil akar, tinggi tanaman, serapan $\mathrm{N}$ dan $\mathrm{P}$ Fase Awal Generatif, persentase polong hampa, produksi perplot, berat $100 \mathrm{biji}$, brangkasan kering.

\section{Hasil Dan Pembahasan}

\subsection{Hasil Analilis Tanah Awal}

Hasil analisis kimia tanah awal yaitu tanah gambutn yang diambil dari lahan penelitia di kampus II Unisi Fakultas Pertanian Jl. Lintas Propinsi Parit 01, Desa Pulau Palas, Kecamatan Tembilahan Hulu, Kabupaten Indragiri Hilir Propinsi Riau dapat dapat dilihat dilihat pada

Table 1. analisis kandungan tanah gambut dari parit 01 Desa Pulau Palas,

Kecamatan Tembilahan Hulu, Kabupaten Indragiri Hilir Propinsi Riau

\begin{tabular}{|l|l|l|l|l|}
\hline No & Jenis Analisis & Satuan & Nilai & criteria \\
\hline 1 & pH H2O & & 5,25 & Agak \\
\hline
\end{tabular}

\begin{tabular}{|l|l|l|l|l|}
\hline 2 & $\mathrm{~N}$ & $\%$ & 0,49 & masam* \\
3 & $\mathrm{P}$ & $\%$ & 0,39 & Sedang* \\
4 & $\mathrm{~K}$ & $\mathrm{Cmol} / \mathrm{kg}$ & 0,72 & Rendah* \\
5 & $\mathrm{Ca}$ & $\mathrm{Cmol} / \mathrm{kg}$ & 1,62 & $\begin{array}{l}\text { Sedang* } \\
\text { Rendah** }\end{array}$ \\
\hline
\end{tabular}

\subsection{Analisis}

Table 2. analisis kandungan Hara POC

\begin{tabular}{|c|c|c|c|c|c|c|c|}
\hline $\bar{N}$ & $\begin{array}{l}\text { POC } \\
\text { limbah } \\
\text { tanama } \\
\text { n } \\
\text { pisang }\end{array}$ & $\begin{array}{l}\text { Nila } \\
\text { i }\end{array}$ & $\begin{array}{l}\text { Satua } \\
n\end{array}$ & $\begin{array}{l}\text { POC } \\
\text { sayu } \\
\text { r kol }\end{array}$ & $\begin{array}{l}\text { Nila } \\
\text { i }\end{array}$ & $\begin{array}{l}\text { Satua } \\
n\end{array}$ & $\begin{array}{l}\text { Syara } \\
\mathrm{t} \\
\text { Mutu }\end{array}$ \\
\hline 1 & $\mathrm{pH}$ & 4,5 & $\%$ & $\mathrm{pH}$ & 4 & $\%$ & $4-8$ \\
\hline 2 & $\mathrm{~N}$ & 0,0 & $\%$ & $\mathrm{~N}$ & 0,0 & $\%$ & $<2$ \\
\hline 3 & $P$ & 7 & $\%$ & P & 5 & $\%$ & $<2$ \\
\hline 4 & K & $\begin{array}{l}0,0 \\
5 \\
0,0 \\
8\end{array}$ & $\%$ & K & $\begin{array}{l}0,0 \\
2 \\
0,0 \\
4\end{array}$ & $\%$ & $<2$ \\
\hline
\end{tabular}

\subsection{Jumlah Bintil Akar}

Analisis sidik ragam pengaruh pemberian pupuk organic cair (POC) asal limbah tumbuhan tidak berpengaruh nyata pada jumlah bintil tanaman kedelai. Rata-rata jumlah bintil akar tanaman kedelai dapat dilihat pada table 3 .

Tabel 3. Rata-rata jumlah bintil akartanaman kedelai akibat pemberian pupuk organik cair asal limbah tumbuhan

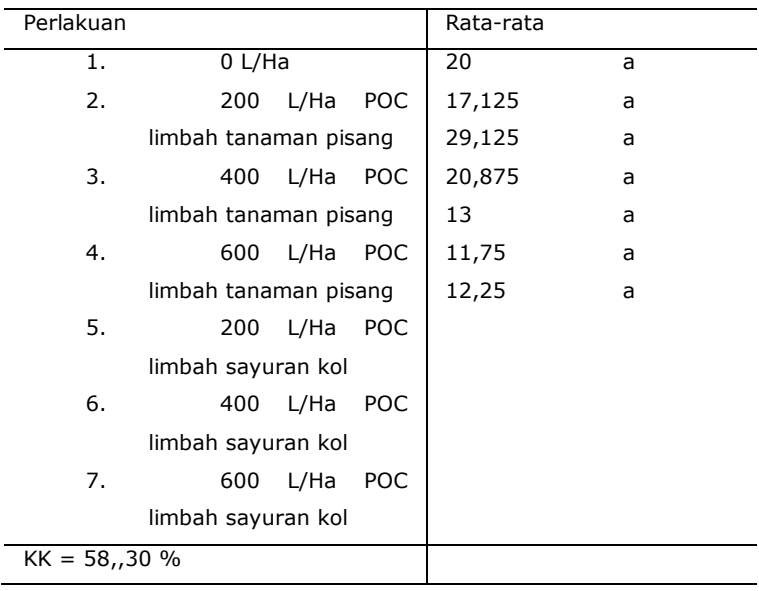

4.4. Serapan N Fase Awal Generative ( Me/100g)

Tabel $4 . \quad$ rata-rata serapan hara $\mathrm{N}$ tanaman kedelai akibat pemberian pupuk organik cair asal limbah tumbuhan.

\begin{tabular}{cll|ll}
\hline Perlakuan & & & \\
\hline 1. & $0 \mathrm{~L} / \mathrm{Ha}$ & & 61,67 & \\
2. & $200 \quad \mathrm{~L} / \mathrm{Ha} \quad$ POC & 64,068 & $\mathrm{a}$ \\
\hline
\end{tabular}




\begin{tabular}{|c|c|c|c|c|}
\hline \multicolumn{3}{|c|}{ limbah tanaman pisang } & 77,912 & $a$ \\
\hline 3. & L/Ha & POC & 72,949 & a \\
\hline \multicolumn{3}{|c|}{ limbah tanaman pisang } & 50,847 & a \\
\hline 4. & $\mathrm{~L} / \mathrm{Ha}$ & POC & 50,468 & a \\
\hline \multicolumn{3}{|c|}{ limbah tanaman pisang } & 69,878 & a \\
\hline 5. & $\mathrm{~L} / \mathrm{Ha}$ & $\mathrm{POC}$ & & \\
\hline \multicolumn{3}{|c|}{ limbah sayuran kol } & & \\
\hline 6. & L/Ha & $\mathrm{POC}$ & & \\
\hline \multicolumn{3}{|c|}{ limbah sayuran kol } & & \\
\hline 7. & L/Ha & $\mathrm{POC}$ & & \\
\hline \multicolumn{3}{|c|}{ limbah sayuran kol } & & \\
\hline
\end{tabular}

\subsection{Serapan P Fase Awal Generative (Me/100g)}

Tabel 5.

Rata-rata serapan hara P

tanamana kedelai akibat

pemberian pupuk organic cair

asal limbah tumbuhan.

\begin{tabular}{|c|c|c|c|}
\hline \multicolumn{2}{|l|}{ Perlakuan } & \multicolumn{2}{|c|}{ Rata-rata } \\
\hline 1. & $0 \mathrm{~L} / \mathrm{Ha}$ & 4,0333 & $\bar{a}$ \\
\hline 2. & 200 L/Ha POC limbah & 4,5333 & a \\
\hline & Ian pisang & 4,76 & a \\
\hline 3. & 400 L/Ha POC limbah & 4,3 & a \\
\hline & lan pisang & 3,5 & a \\
\hline 4. & 600 L/Ha POC limbah & 3,8633 & a \\
\hline & lan pisang & 4,6 & $\mathrm{a}$ \\
\hline 5. & 200 L/Ha POC limbah & & \\
\hline & an kol & & \\
\hline 6. & 400 L/Ha POC limbah & & \\
\hline & an kol & & \\
\hline 7. & 600 L/Ha POC limbah & & \\
\hline & an kol & & \\
\hline
\end{tabular}

\subsection{Tinggi Tanaman ( $\mathrm{Cm}$ )}

Tabel $6 . \quad$ Rata-rata tinggi tanaman $(\mathrm{cm})$ kedelai akibat pemberian pupuk organic asal limbah tumbuhan.

\begin{tabular}{|c|c|c|c|}
\hline Perlakuar & & Rata-rat & \\
\hline 1. & $0 \mathrm{~L} / \mathrm{Ha}$ & 59,375 & $a$ \\
\hline 2. & 200 L/Ha POC & 64,125 & a \\
\hline & tanaman & 71,625 & $a$ \\
\hline & pisang & 64,250 & $a$ \\
\hline 3. & 400 L/Ha POC & 58,750 & $a$ \\
\hline & tanaman & 63,250 & $a$ \\
\hline & pisang & 66,125 & $a$ \\
\hline 4. & 600 L/Ha POC & & \\
\hline & tanaman & & \\
\hline & pisang & & \\
\hline 5. & 200 L/Ha POC & & \\
\hline & limbah sayuran kol & & \\
\hline 6. & 400 L/Ha POC & & \\
\hline & limbah sayuran kol & & \\
\hline 7. & 600 L/Ha POC & & \\
\hline & limbah sayuran kol & & \\
\hline $\mathrm{KK} \mathrm{N}=1$ & $71 \%$ & & \\
\hline
\end{tabular}

\subsection{Persentase Polong Hampa (\%)}

Tabel $7 . \quad$ Rata-rata polong hampa tanaman kedelai akibat pemberian pupuk organic cair asal limbah tumbuhan.

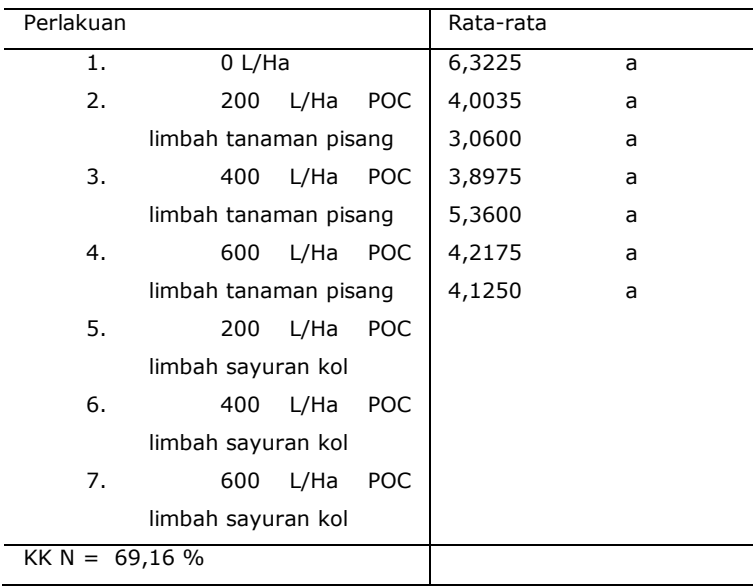

\subsection{Produksi (G/Plot) Dan (Ton/Hektar)}

Table $8 . \quad$ rata-rata jumlah produksi perplot tanaman kedelai akibat pemberian pupuk organic cair asal limbah tumbuhan.

\begin{tabular}{|c|c|c|c|c|c|}
\hline \multicolumn{2}{|c|}{ Perlakuan } & \multicolumn{2}{|c|}{$\begin{array}{c}\text { Rata-rata } \\
\text { ( g/plot) }\end{array}$} & \multicolumn{2}{|c|}{$\begin{array}{l}\text { Rata-rata } \\
\text { (ton/ha) }\end{array}$} \\
\hline \multirow[t]{2}{*}{1.} & 0 & 176,87 & C & 0,05 & c \\
\hline & L/Ha & 224,22 & c & 0,064 & c \\
\hline \multirow[t]{5}{*}{2.} & 200 & 390,09 & c & 0,11 & a \\
\hline & L/Ha POC & 265,99 & bc & 0,077 & bc \\
\hline & limbah & 106,45 & d & 0,030 & d \\
\hline & tanaman & 259,98 & b & 0,075 & b \\
\hline & pisang & 359,22 & $a b$ & 0,010 & $a b$ \\
\hline \multirow[t]{5}{*}{3.} & 400 & & & & \\
\hline & $\mathrm{L} / \mathrm{Ha} \quad \mathrm{POC}$ & & & & \\
\hline & limbah & & & & \\
\hline & tanaman & & & & \\
\hline & pisang & & & & \\
\hline \multirow[t]{5}{*}{4.} & 600 & & & & \\
\hline & $\mathrm{L} / \mathrm{Ha} \quad \mathrm{POC}$ & & & & \\
\hline & limbah & & & & \\
\hline & tanaman & & & & \\
\hline & pisang & & & & \\
\hline \multirow[t]{4}{*}{5.} & 200 & & & & \\
\hline & L/Ha POC & & & & \\
\hline & limbah & & & & \\
\hline & sayuran kol & & & & \\
\hline \multirow[t]{4}{*}{6.} & 400 & & & & \\
\hline & L/Ha POC & & & & \\
\hline & limbah & & & & \\
\hline & sayuran kol & & & & \\
\hline \multirow[t]{2}{*}{7.} & 600 & & & & \\
\hline & $\mathrm{L} / \mathrm{Ha} \quad \mathrm{POC}$ & & & & \\
\hline
\end{tabular}




\begin{tabular}{|r|r|r|}
\hline $\begin{array}{l}\text { limbah } \\
\text { sayuran kol }\end{array}$ & & \\
\hline $\mathrm{KK}=18,21 \%$ & & \\
\hline
\end{tabular}

\subsection{Berat 100 Biji Pada Kadar Air 14\% (G)}

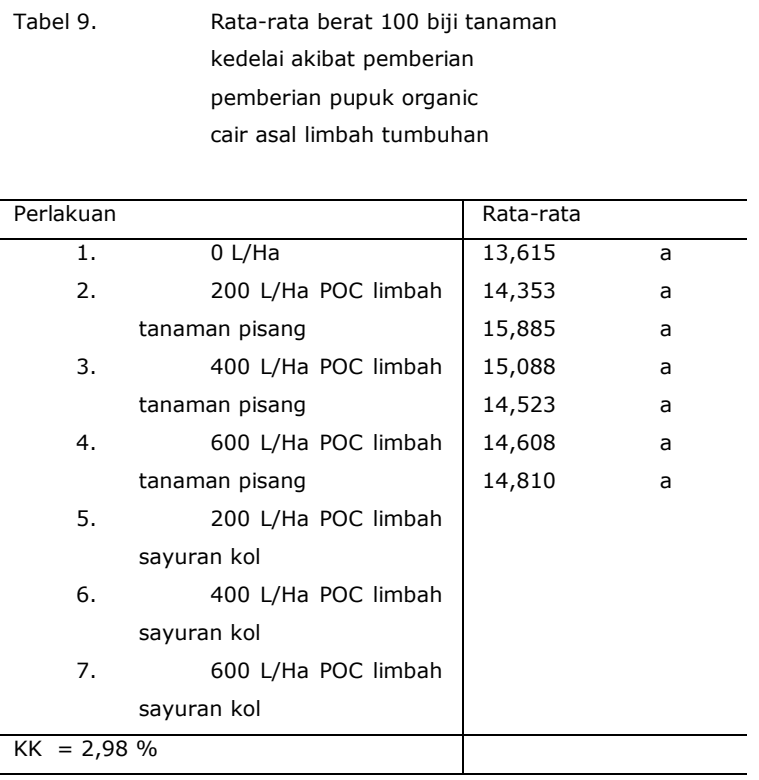

\subsection{Brangkasan Kering (G)}

Tabel 10. Rata-rata brangkasan kering tanaman kedelai akibat pemberian pupuk

organic cair asal limbah tumbuhan

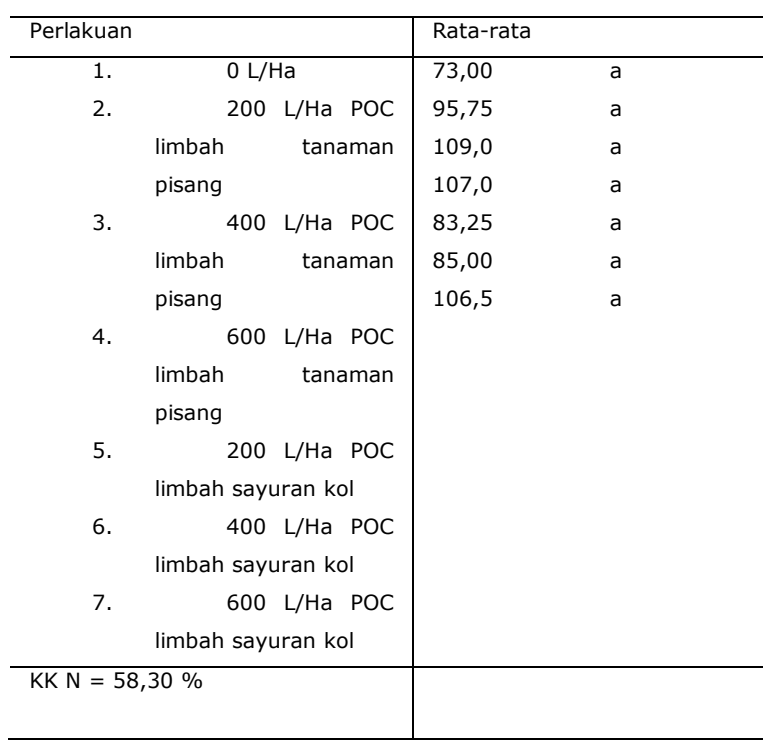

5. Kesilmpulan Dan Saran

\subsection{Kesimpulan}

Berdasarkan hasil penelitian yang telah dilaksanakan dapat disimpulkam bahwa :
1. Pemberian pupuk organic cair ( $P O C$ ) asal limbah tumbuhan (limbah tanaman pisang dan kol ) tidak berpengaruh nyata terhadap serapan $\mathrm{N}$ dan $\mathrm{P}$ tanaman kedelai.

2. Pemberian POC asal limbah tumbuhan ( limbah tanaman pisang dan limbah sayur kol) terbukti mampu meningkatkan produksi tanaman kedelai di tanah gambut. Produksi pemberian POC limbah tanaman pisang tertinggi pada dosis $400 \mathrm{~L} / \mathrm{Ha}$ menghasikan 0,11 ton/hektar da pada POC sayr kol produksi tertinggi dengan dosis 600 L/Ha mampu menghasilkan 010 ton/hektar.

\subsection{Saran}

Perlu penelitian lanjutan untuk mencari dosis yang tepat pupuk organic cair (POC) asal limbah tumbuhan untuk tanaman kedelai yang ditanam di lahan gambut.

\section{DAFTAR PUSTAKA}

Hardjowigeno. S. 2003. ilmu tanah. akademika pressindo : Bogor. Suprapto. 2002. Bertanam kedelai. Penebar swadaya. jakarta 